\title{
Evaluating THE COST-EFFeCTIVENESS OF ECOSYSTEM-BASED AdAPTATION: KAMIESBERG WeTLANDS CASE STUdY
}

\author{
David Black and Jane K Turpie \\ Environmental-Economics Policy Research Unit (EPRU), University of Cape Town
}

\section{Nalini Rao}

Conservation International, United States of America

Accepted: July 2016

\begin{abstract}
Ecosystem-based adaptation ( $\mathrm{EbA})$ is increasingly being promoted as a cost-effective means of adaptation to climate change. However, in spite of considerable international press, there is still little evidence to substantiate this claim. This study proposes a method through which the cost-effectiveness of EbA strategies can be evaluated against alternative adaptation options, and contributes to South African literature on the subject. The potential cost-effectiveness of wetland restoration is assessed as a means of securing the carrying capacity of land for pastoralist communities of the Kamiesberg communal area in South Africa under projected future climate conditions. The conventional alternatives would be to respond to increasingly dry conditions by drilling boreholes and using supplemental feed for livestock. It was assumed that the EbA interventions would occur upfront, whereas the alternatives are more likely to be implemented in reaction to droughts over a longer time period. The study found the implementation of conventional alternatives to be more cost-effective than EbA as a means to sustaining livestock stocking rates, with EbA being twice as costly. However, this is framed from the perspective of those directly affected (the landowners), and does not include the benefits to broader society.
\end{abstract}

Key words: climate change, ecosystem-based adaptation, cost-effectiveness, South Africa, wetlands

JEL: Q51, 54, 57

\section{Introduction}

With the pressing need for climate change adaptation strategies, the concept of ecosystem-based adaptation $(\mathrm{EbA})$ is increasingly being brought to the fore (Vignola, Locatelli, Martine \& Imbach, 2009; Huq, Renaud \& Sebesvari, n.d.). Ecosystems can provide a range of services that are beneficial to humans. The tenet of EbA is that a community's resilience to future climate change stress can be increased through the restoration, conservation and maintenance of supporting ecosystems (Vignola et al., 2009; Ainley, Perez, Andrianarisata, Barnes \& Beck et al., 2010; Doswald \& Osti, 2011; Munroe, Doswald, Roe, Reid \& Giuliani et al., 2011; Munang, Thiaw, Alverson, Mumba \& Liu et al., 2013; Midgley, Marais, Barnett \& Wågsæther, 2012; Secretariat of the Convention on Biodiversity, 2009). Conventional approaches to climate change adaptation typically include artificial, engineered solutions. In contrast, EbA can result in a range of additional benefits for both biodiversity and local communities (Huq et al., n.d.; Ainley et al., 2010; Munang et al., 2013; Campbell, Kapos, Scharlemann, Bubb \& Chenery et al., 2009). In some instances it has also been found to be a more cost-effective approach than conventional approaches (Munang et al., 2013; Naumann, Anzaldua, Gerdes, Frelih-Larsen \& Davis et al., 2011; Rao, Carruthers, Anderson, Sivo \& Saxby et al., 2012; Midgley et al., 2012).

The evidence base to support the implementation of EbA strategies is growing both internationally and within Southern Africa (Munroe et al., 2011; Midgley et al., 2012; Ziervogel, New, Van Garderen, Midgley \& Taylor et al., 2014), where the majority of these case studies is built around qualitative analyses for policy and strategic recommendations (Doswald \& Osti, 2011; Munroe et al., 2011; Naumann et al., 2011; Munroe et al., 2012; UNFCC, n.d.; Midgley et al., 2012; Birch , Newton, Aquino, Cantarello \& Echeverría et al. 2010). However, while currently 
limited, there is an increasing focus on quantitative scientific analyses of the cost-effectiveness of EbA strategies relative to more conventional climate change adaptation options (Jones, Hole \& Zavaleta, 2012; Birch et al., 2010; Hoang Tri, Adger \& Kelly, 1998; Batker, de la Torre, Costanza, Swedeen \& Day et al., 2010; TEEB, 2010; Russi, ten Brink, Farmer, Badura \& Coates et al., 2013).

This study proposes a method through which the cost-effectiveness of EbA strategies can be evaluated against alternative adaptation options. The application of this method is demonstrated through a case study of wetland rehabilitation in the Kamiesberg uplands of Namaqualand in the Northern Cape, South Africa - a semi-arid region which is home to pastoralist communities.

South Africa's generally water-stressed environment and the magnitude of its socio-economic challenges make it particularly vulnerable to climate variability and change. Different regions of the country are likely to be affected in many different ways, and impacts on people, biodiversity and the water sector are likely to be considerable, and will add additional pressure to systems already facing significant stress (Bourne, Donatti, Holness \& Midgley, 2012; Schulze, 2011; Ziervogel et al., 2014; DEA, 2013b; DEA, 2013a). For the Succulent Karoo Biome of Namaqualand, the climate will become hotter and drier, with more intense storms, floods and droughts (Bourne et al., 2012). For the Kamiesberg region, temperature increases will most likely be moderated by altitude, where average temperatures are projected to increase by between $2^{\circ} \mathrm{C}$ and $3^{\circ} \mathrm{C}$ over the next 100 years (Bourne et al., 2012; Schulze, 2011). Rainfall is projected to be reduced to $90-100$ per cent of present by 2050, and 70-80 per cent of present by 2100 (Schulze 2011). These projections are further reinforced by those of the Climate Systems Analysis Group (CSAG) (CIP, 2014), where, on average across months, rainfall in nearby Springbok (approximately $60 \mathrm{~km}$ to the north; and similarly Vredendal, approximately $160 \mathrm{~km}$ to the south of the Kamiesberg) is projected to decrease for the period 2030-2050, and further decrease for the period 2070-2090, relative to the historical period of 1980-2000 under the more conservative RCP (Representative Concentration Pathway) 4.5. Minimum and maximum temperatures for Springbok (and similarly for Vredendal) are projected to increase for the period 2030-2050, and further increase for the period 2070 - 2090, relative to the historical period of 1980-2000, under the RCP 4.5. Given the already arid nature of Namaqualand, this could have significant implications. Adapting to the predicted effects of climate change is therefore an imperative.

The rural villages of the Leliefontein communal area are characterised by low economic activity and high unemployment (Bourne et al., 2012; Samuels, 2013). While communal farming is an important livelihood source in the Leliefontein communal area, communities typically rely on a combination of several livelihood sources (Benjaminsen, Rohde, Sjaastad, Wisborg \& Lebert, 2006) including wage labour (commercial farms, schools, the Working for Wetlands programme, government posts or shops), remittances and government grants, where livestock farming represents a "hedge against fluctuations in other incomes" (Ellis, 2013, oral communication, June 18; Benjaminsen et al., 2006). Due to the arid nature of the region, livestock farmers have long since adopted transhumance strategies in response to seasonal differences in grazing and the scarcity of water resources (Hill, Archer \& Webley, 1990), where the wetlands of the Kamiesberg uplands are a key focus-point. The communities rely on the wetlands as a critical support system for livestock owing to their ability to continue to retain water and quality forage throughout the dry summer months of the year (Samuels, 2013; Kotze, Malan, Ellery, Samuals \& Saul, 2010). The wetlands also provide other benefits, such as erosion control and flow regulation (Kotze et al., 2010). However, over time, many of these wetlands have been severely degraded through cultivation and overgrazing. The reliance of the local communities on these degraded ecosystems, predominantly through pastoralist activities, accentuates their vulnerability to the projected pressures of climate change.

Based on the socio-ecological vulnerabilities of the region, the principle of EbA to climate change is strongly aligned with the challenges faced by these communities. This study therefore analyses the cost-effectiveness of wetland rehabilitation in the Kamiesberg uplands relative to 'conventional alternatives', where 'conventional alternatives' include the installation of boreholes 
and the importation of dry feed (maize and lucerne) into the Leliefontein communal area. The study is framed by the objective of sustaining livestock stocking rates into the future, and specifically from the perspective of those directly affected (the landowners). It does not seek to quantify the benefits to broader society.

\section{Study Area}

\subsection{Location and extent of study area}

The study area has been defined as that which falls within the Kamiesberg uplands (above $800 \mathrm{~m}$ above mean sea level (amsl)), and within the Leliefontein communal area (see Figure 1). The Leliefontein communal area is one of six communal areas in the Namaqualand region, and falls within the Namakwa District Municipality of the Northern Cape Province of South Africa (Samuels, 2013; Agricultural Research Council - Animal Production Institute, 2012). The communal area is approximately 192000 hectares in size (Samuels, 2013; Agricultural Research Council - Animal Production Institute, 2012), and is divided into ten village commons. These village commons have unfenced and permeable boundaries, and vary between 12000 and 25000 hectares (Samuels, 2013). The area above $1200 \mathrm{~m}$ amsl in the Kamiesberg is a centre of endemism within the Succulent Karoo Biome (Helme \& Desmet, 2006), which mostly extends up the western flank of South Africa (Mucina \& Rutherford, 2006). The vegetation in the Kamiesberg uplands have changed significantly as a result of heavy grazing and cultivation.

Figure 1

The location and extent of the study area (based on wetland data from Job (2008))

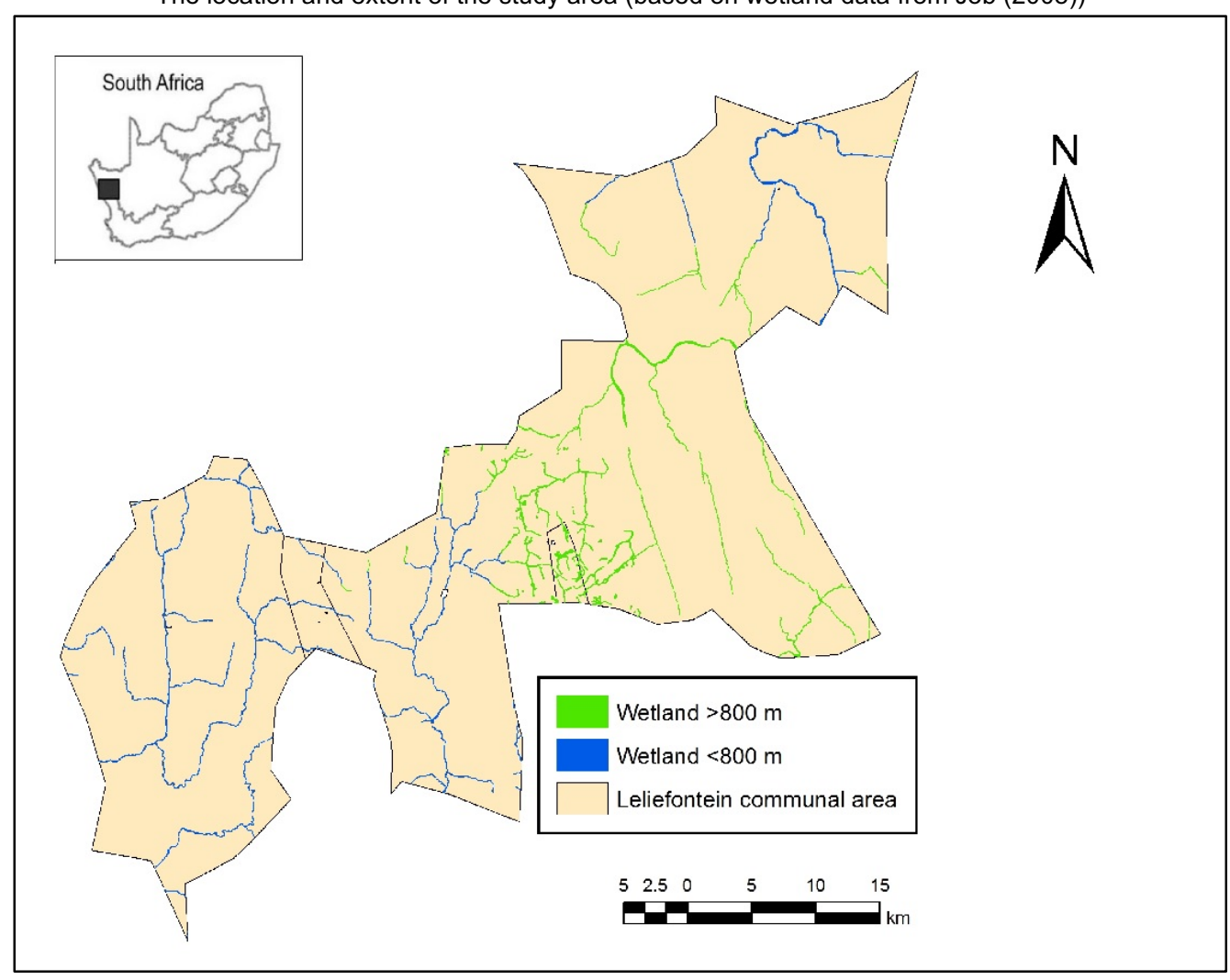




\subsection{Wetlands}

Wetlands generally provide a number of ecosystem services that are beneficial to people, including, amongst others: flood attenuation; provision of water; provision of livestock fodder; nutrient cycling and the amelioration of pollution; erosion control; the provision of harvestable resources; and refugia (Kotze et al., 2010; Agricultural Research Council - Animal Production Institute, 2012). While these benefits can be quantified according to their direct and indirect use values, the data collection requirements are onerous, and this was outside the scope of the study.

Just under 1 per cent (1750 ha) of the Leliefontein communal area comprises small ephemeral wetlands (calculations based on wetland data from Job (2008)). These wetlands are generally located on sedimentary fill sequences situated between steeply-sloped granitic outcrops. Shallow soils, combined with the steep terrain results in high run-off discharges through the upper catchments of the Kamiesberg (Kotze et al., 2010). According to Kotze (Kotze, 2013, oral communication, July 25), these wetlands act to reduce run-off velocity within their surrounding catchments, allowing water to permeate through the underlying soil. While this may not recharge the deep aquifers of the region, these wetlands are integral to the recharge of shallow sub-surface water, the presence of which is vital to the existence of springs and water levels that are accessible to livestock in dug wells. The capacity of these wetlands to provide a range of ecosystem services varies with their hydro-geomorphic type, attributes and level of functionality. Hydro-geomorphic wetland types within the study area vary between valley bottom with a channel, valley bottom without a channel and hill slope seeps (Kotze et al., 2010).

More than 60 per cent of the wetlands in the Kamiesberg uplands have been severely degraded (Helme \& Desmet, 2006) by the removal of indigenous vegetation, over-burning, cultivation, overgrazing, roads, the over-abstraction of water and the establishment of alien tree stands (predominantly Populus sp. and Eucaluptus sp.). In some cases this has resulted in the severe onset of erosion, loss of ecological integrity, and changes to the wetlands' hydrological regimes (Kotze, 2013, oral communication, July 25).

Rehabilitation efforts have been carried out in some of these wetlands by the Working for Wetlands programme, where efforts include alien clearing, revegetation and the installation of gabions, concrete structures, earth works and earth structures.

\section{Methods}

A cost-effectiveness analysis was undertaken to evaluate the implementation of EbA options compared to alternative measures to deal with the expected impacts of climate change. Climate change is likely to exacerbate the pressures that are already faced by people living in the Leliefontein communal area, through desiccation of agricultural lands, reduced grazing capacity and reduced water availability. Restoration of the degraded wetlands could reduce these impacts through restoring the provision of their services, and with that improve the resilience of the socioecological system. In this instance, wetland restoration was therefore considered as a form of EbA.

The restoration of wetlands was compared to 'conventional alternatives' that would otherwise need to be implemented in the future in order to continue to sustain livestock stocking rates, where these 'conventional alternatives' included the installation of boreholes, and the importation of dry feed (maize and lucerne) into the Leliefontein communal area. The costs associated with the conventional alternatives are outlined below.

The timing of these alternative types of investments (EbA vs conventional alternatives) would not be the same. While ecosystem restoration would need to occur in the near future in order to realise benefits over the medium to long term, the 'conventional alternatives' were expected to be implemented only once the predicted pressures of climate change became locally evident. Although these 'conventional alternatives' might be implemented in response to severe drought periods, the probability of these drought periods occurring in any given year is essentially equal across all years. Thus, annual 'conventional alternatives' costs were averaged out up to 2050, and 
discounted to the present using discount rates of 3 per cent, 5 per cent and 8 per cent, and subsequently summed for comparison.

\subsection{Wetland rehabilitation costs}

The ecological rehabilitation actions implemented by Working for Wetlands in the past (from the 2010 to the 2013 financial year) include alien clearing, revegetation, the installation of gabion structures, concrete structures, and earth structures. These rehabilitation actions have only been implemented on a few wetlands, and areas surrounding wetlands, in and just outside of the Leliefontein communal area. The initial costs of these rehabilitation options were obtained from Working for Wetlands, and then inflated to the 2013 financial year using the South African Producer Price Index (PPI) (see Table 1).

Table 1

Expenditure on rehabilitation of wetlands within the study area, excluding follow-up or maintenance costs*

\begin{tabular}{|l|c|c|c|c|c|c|r|r|r|}
\hline \multicolumn{1}{|c|}{ Wetland } & Ha & $\begin{array}{c}\text { Revege- } \\
\text { tation }\end{array}$ & $\begin{array}{c}\text { Removal of } \\
\text { alien trees }\end{array}$ & $\begin{array}{c}\text { Gabion } \\
\text { structures }\end{array}$ & $\begin{array}{c}\text { Concrete } \\
\text { structures }\end{array}$ & $\begin{array}{c}\text { Earth } \\
\text { structures }\end{array}$ & $\begin{array}{c}\text { Earth } \\
\text { works }\end{array}$ & Total & $\begin{array}{c}\text { Total per } \\
\text { ha }\end{array}$ \\
\hline $\begin{array}{l}\text { Mid- } \\
\text { Eselfontein }\end{array}$ & 10 & 1230 & & & & & 75011 & 76240 & 7624 \\
\hline Suurhoek & 10.6 & 5540 & & 209678 & 158263 & 142152 & & 515632 & 48645 \\
\hline $\begin{array}{l}\text { Upper- } \\
\text { Eselfontein }\end{array}$ & 3 & & 17284 & & & & & & \\
\hline Groenkloof & 2 & & 3088 & 1273553 & 168588 & & & 1445229 & 722615 \\
\hline Skaaprivier & 1.8 & & 5714 & & & & & 5714 & 3175 \\
\hline Blokdrif & 2.03 & & 5714 & & & & & 5714 & 2815 \\
\hline Hoorngaat & 3.31 & & 20000 & & & & & 20000 & 6042 \\
\hline Xharas & 2.5 & & 19883 & 206020 & 1030277 & & 32099 & 1288279 & 515312 \\
\hline Leliefontein & 1.6 & & 30355 & & 466562 & & & 496917 & 310573 \\
\hline Witsand & 0.2 & & & & 1385730 & & 21326 & 1407056 & 7035281 \\
\hline Total & $\mathbf{3 7 . 0 4}$ & & & & & & & $\mathbf{5 3 0 9 8 3 5}$ & $\mathbf{1 4 3 3 5 4}$ \\
\hline
\end{tabular}

Source: Working for Wetlands (2013)

*All costs converted to 2013 rands

It was assumed that the initial intervention would take place in the 2013 financial year, and maintenance actions would be carried out over the following ten years, to ensure the effective rehabilitation of the wetlands, to the degree to which their provision of ecosystem services is restored. These maintenance costs were conservatively estimated at an annual average of 5 per cent of the cost of initial intervention. As the cost per unit differs across ecological rehabilitation options (cost per hectare for alien clearing and revegetation, and cost per $\mathrm{m}^{3}$ for gabion structures, concrete structures, earth works and earth structures), the costs per unit for all the rehabilitation actions were standardised to the cost per wetland area that would be rehabilitated. The type of rehabilitation required by wetlands within the study area also varies greatly from one wetland to another. It is thus impossible to determine the specific rehabilitation actions required by each wetland across such a broad area without detailed evaluation, and the average of the costs per wetland area was taken based on the average overall combination of rehabilitation actions.

The area of wetlands within the Kamiesberg that also falls within the Leliefontein communal area, and above $800 \mathrm{~m}$ amsl was determined to be approximately 917 hectares using a geographic information system (GIS). Since at least 60 per cent of the wetlands have been severely degraded (Helme \& Desmet, 2006), the total cost of rehabilitation was based on an estimated 65 per cent of the wetland area, which equates to the rehabilitation of 596 hectares of wetland.

\subsection{Conventional altermatives}

Without intervention, it was assumed that the continued degradation of the wetlands combined with the projected pressures of climate change would result in further loss of wetland services in 
the future. The implementation of 'conventional alternatives' included supplementary feeding of livestock as well as construction of boreholes for water supply. The amount of investment required was estimated for the climate situation projected for 2050 . The implementation of these measures was projected to increase over time as climate change effects increased. As there is uncertainty surrounding both climate change projections and the way in which the communities and municipalities will react to these pressures in the future, alternative assumptions were explored as to the timing and extent of the introduction of these measures.

The 2050 requirements for feed and boreholes were estimated as follows. The livestock farmed within the Leliefontein communal area is predominantly made up of small stock (mainly boer goats and dorper sheep), with very few cattle (Basson, 2013, oral communication, 6 September) (Samuels, 2013). It was assumed that the carrying capacity of the surrounding rangeland vegetation would be the limiting factor with regards to the year-round stocking rates in the Leliefontein communal area, and that supplementary feed would be required to replace the contribution that wetlands make to grazing. Samuels (2013) recorded the variations in the livestock stocking rates (SSU/10 hectares) over the whole of the Leliefontein communal area for the period 1999-2006. To calculate the extent to which the wetlands of the Kamiesberg uplands enable farmers to sustain their livestock stocking rates through the dry summer months of the year, the differential between the summer livestock stocking rates in the wetlands of the Kamiesberg uplands, and the average livestock stocking rates for the rest of the Leliefontein communal area was estimated. This suggests that the wetlands of the Kamiesberg uplands enable farmers to sustain an additional $0.563 \mathrm{SSU} / 10$ hectares under the conditions during that period. The costs of substituting the wetland fodder with dry feed (maize and lucerne) was estimated based on the cost of supplying dry feed for the peak summer months of the year, when wetlands would normally be relied upon. The requirement under expected 2050 conditions was estimated to be 90 days of feed for 51.64 SSU (the product of the stocking rate differential and the total area covered by wetlands within the study area). Based on feed requirements (Le Maitre et al., 2009), and current market prices for maize (R2 600 per ton) and lucerne (R3 000 per ton) (Kaap Agri, 2013, oral communication, 12 September), this would cost some R305 per day (Table 2). For sensitivity analysis, the total feed requirement was varied by 30 per cent either way.

Table 1

Estimated cost of feed, based on Department of Agriculture's recommended dry feed diet ()

\begin{tabular}{|l|c|c|c|c|c|c|} 
& $\begin{array}{c}\text { Per 50kg } \\
\text { SSU/Day (kg) }\end{array}$ & $\begin{array}{c}\text { Price of feed } \\
(\mathbf{R} / \mathbf{t})\end{array}$ & $\begin{array}{c}\text { Price of feed } \\
\mathbf{( R / k g )}\end{array}$ & $\begin{array}{c}\text { Price of feed } \\
\text { (R/SSU) }\end{array}$ & $\begin{array}{c}\text { TOTAL (R/SSU/ } \\
\text { Day): }\end{array}$ & $\begin{array}{c}\text { Subst. } \\
\text { Wetlands } \\
\text { (R/Day) }\end{array}$ \\
\hline Maize & 0.25 & 2600 & 2.6 & 0.65 & \multirow{2}{*}{$\mathbf{5 . 9}$} & $\mathbf{3 0 4 . 6 7 6}$ \\
\hline Lucerne & 1.75 & 3000 & 3 & 5.25 & & \\
\hline
\end{tabular}

Source: Le Maitre et al. (2009)

It was assumed that the feed requirement would increase every year in relation to increasing climate stress, eventually reaching the expected 2050 feed requirement. As it is difficult to justify a specific non-linear relation on solid ground, it was assumed that this increase would be roughly linear.

Livestock in the Leliefontein communal area obtain drinking water from a number of different sources: dug wells in wetlands; boreholes; springs; and dams (Samuels, 2013). The number of livestock drinking sources within the study area was calculated from data compiled by the Agricultural Research Council (Table 3).

These wetlands play an integral role in recharging the shallow sub-surface groundwater of the Kamiesberg (Kotze, 2013, oral communication, July 25). Therefore, if the degradation of these wetlands is allowed to continue, combined with the predicted pressures of climate change, the assumption is that the wetlands of the Kamiesberg will in the future no longer be a source of water for livestock, and that the springs and dug wells will need to be substituted with the installation of boreholes - a total of 46. It was assumed that boreholes are installed gradually over time as 
conditions deteriorate. Although it could reasonably be argued that borehole installation is likely to be concentrated around drought events, since the timing of these drought events is unknown, the result will be equivalent if the relative probability of drought in each period is unknown and assumed to be equal. For sensitivity analysis, the total borehole requirement was varied by 30 per cent either way.

Table 3

Livestock drinking sources within the study area

\begin{tabular}{|l|c|}
\hline \multicolumn{2}{|c|}{ Livestock drinking sources } \\
\hline Type & Number \\
\hline Dug wells & 28 \\
\hline Boreholes & 21 \\
\hline Springs & 18 \\
\hline Dams & 2 \\
\hline Total: & $\mathbf{6 9}$ \\
\hline
\end{tabular}

Source: Samuels (2013)

Borehole installation costs were obtained from MEK Drilling, based in Vanrhynsdorp. A quote was obtained for the drilling of a borehole in the Kamiesberg region specifically, to a depth of 100 $\mathrm{m}$ (with an assumed water availability at $50 \mathrm{~m}$ below the surface). The quote includes the costs associated with drilling, casing, concrete collar, and a solar pump (no fuel costs entailed) with two solar panels. The quoted total cost for installing a borehole in the Kamiesberg region is R105 588 (as at 16 September 2013). According to Vollgraaff (Vollgraaff, 2013, oral communication, September 16), once the boreholes have been installed, no regular maintenance is required, unless under exceptional circumstances.

\section{Resullts}

The cost estimates of wetland restoration were extremely variable, depending on the type of work required. This resulted in markedly different lower and upper bound estimates of R4.93 million and R112.87 million, respectively, for a discount rate of 5 per cent (Table 4). While it is likely that the wetlands that have been rehabilitated are those that required the most structural work, it is unlikely that no other wetlands need this kind of work. Thus the actual cost is likely to lie closer to the lower bound than the upper bound value. Nevertheless, the lower bound estimate is higher than all estimates of costs of the conventional alternatives. Using our primary assumptions and a discount rate of 5 per cent, these are estimated to be about R2.33 million, but range from R1.13 to R4.08 million depending on assumptions and discount rate (Table 5). As the choice of the appropriate discount rate is a subject of debate, three different discount rates were used ( 3 per cent, 5 per cent and 8 per cent) to serve as a sensitivity analysis.

Note that the choice of discount rate has less of an effect on the wetland rehabilitation option than on the conventional alternatives, because the former investment is mainly upfront, whereas the latter costs are spread over time up to 2050. At a low discount rate, the lower bound wetland rehabilitation cost is closer in value to the upper bound estimate for the conventional alternatives, but is still higher.

Table 4

Upper and lower bound estimates of the costs of ecosystem-based adaptation through wetland rehabilitation

\begin{tabular}{|l|c|c|c|}
\hline \multirow{2}{*}{\multicolumn{1}{|c|}{ Net present value (R millions) }} & \multicolumn{3}{|c|}{ Discount rate } \\
\cline { 2 - 4 } & $\mathbf{3} \%$ & $\mathbf{5 \%}$ & $\mathbf{8} \%$ \\
\hline Lower bound (only alien clearing required) & R 5.18 & R 4.93 & R 4.62 \\
\hline Upper bound (all measures required) & R 118.41 & R 112.87 & R 105.73 \\
\hline
\end{tabular}


Table 5

Upper and lower bound estimates of the costs of conventional adaptation through feed supplements and borehole construction

\begin{tabular}{|l|c|c|c|}
\hline \multicolumn{1}{|c|}{ Net present value (R millions) } & \multicolumn{3}{c|}{ Discount rate } \\
\cline { 2 - 4 } & $\mathbf{3} \%$ & $\mathbf{5 \%}$ & $\mathrm{R} 1.13$ \\
\hline Lower bound & $\mathrm{R} 2.19$ & $\mathrm{R} 1.63$ & $\mathrm{R} 1.61$ \\
\hline Primary estimate & $\mathrm{R} 3.13$ & $\mathrm{R} 2.33$ & $\mathrm{R} 2.09$ \\
\hline Upper bound & $\mathrm{R} 4.08$ & $\mathrm{R} 3.02$ & \\
\hline
\end{tabular}

\section{Discussion}

Internationally, the majority of EbA studies are built around some form of qualitative analysis or policy recommendations. While still scarce, quantitative analyses on the cost-effectiveness of EbA strategies are increasing. As a case study, Rao et al. (2012) applied least-cost, benefit-cost, and net present value analyses to storm surge adaptation options for Lami Town, Fiji. In terms of the leastcost analysis, a number of alternatives were analysed, where combinations of these alternatives would need to be implemented in order to achieve the end objective of reducing projected future flooding events associated with climate change. While Lami Town in Fiji is very different from the Northern Cape, the approach to the cost-effectiveness analysis chosen by Rao et al. (2012) is very similar to this study, where costs for each alternative are summed over 10 and 20 year time periods, and discounted to the present using a discount rate of 3 per cent. Rao et al. (2012) found combinations of EbA options to be the most cost-effective in reducing flood risk for Lami Town. Tinch \& Ledoux (2006) assessed the 'managed realignment' of coastal regions in the UK as an EbA strategy against coastal flooding relative to engineering alternatives, in which the costeffectiveness of 'managed realignment' was found to be site-specific. As outlined by Rao et al. (2012) relative to alternative economic analyses, a cost-effectiveness analysis embodies the least amount of uncertainty. Uncertainty rises with the inclusion of benefit estimation. For this reason, a cost-effectiveness analysis should be the first 'port of call' in assessing alternative adaptation options. A full cost-benefit estimation was not attempted in this study because of the onerous data requirements and the uncertainty surrounding the estimation of benefits associated with wetland restoration.

In this study, the implementation of 'conventional alternatives' was found to be more costeffective than the implementation of EbA in the present, as a means to sustaining livestock productivity for the local communities into the future. This represents only the benefits to those directly affected (the landowners), and not the benefits to broader society. The implementation of 'conventional alternatives' was assumed to increase linearly. If, however, a nonlinear relation was specified (e.g. discrete or continuous exponential), the effect on the final costs would depend on the discount period - 'conventional' alternatives would be favoured even further if a greater majority of these alternatives were only implemented further into the future. Restoration of wetlands can be very costly, especially where structural work is required to repair damage caused by draining wetlands for cultivation. This is largely driven by the 'engineered' component (installation of gabions, concrete structures, earth works and earth structure) of the rehabilitation actions. Such high costs are to be expected where rehabilitation strategies are implemented in somewhat 'challenging' wetlands, such as those in the Kamiesberg (wetlands characterised by high gradients and shallow soils) (Kotze, 2013, oral communication, November 08). As an indication, Kotze \& Ellery (2008) found the cost of rehabilitating the Killarney wetland in KwaZulu-Natal, South Africa, to be R223 000 per hectare, and the cost of rehabilitating the Manalana wetland in Mpumalanga, South Africa, to be R947 000 per hectare. In this study, the clearing of invasive alien trees was found to be the cheapest form of restoration, by orders of magnitude, yet this is still a very costly exercise. The actual restoration requirements for the Kamiesberg area have not been assessed, and this presented a serious limitation for this study. It is possible that initial restoration efforts have targeted the most seriously damaged wetlands that 
require structural work, and that much of the remaining work required is alien clearing, which means that the costs would be closer to our lower bound estimate. Nevertheless, these costs would still be twice as high as conventional options (R4.93 million as compared to R2.33 million). This accords with the lower-bound wetland rehabilitation cost estimate, and the primary estimate for conventional adaptation, respectively, both calculated at a discount rate of 5 per cent.

However, this does not necessarily mean that wetland restoration is not a justifiable means of adaptation to climate change, as there are some other issues that also need to be considered. The first of these is who bears the costs and benefits of implementing the adaptation measures. The restoration of wetlands that has up to now taken place in the study area has been undertaken by Working for Wetlands, which is a government-funded poverty-relief programme that aims to provide employment while also restoring ecological integrity and ecosystem services. In this case, it can be argued that the costs associated with EbA implementation can effectively be discounted. However, the conventional adaptation options described above are typically undertaken by landowners, but are unlikely to be affordable to the communities of the study area. While these options could be subsidised by the state, they are less likely to have the same reach in terms of employment benefits as the labour-intensive restoration of wetlands. These economic implications would probably be reflected elsewhere in Namaqualand and across other semi-arid regions within South Africa. But if the implementation of EbA can be shown to make economic sense to those directly affected (the landowners), this suggests a 'win-win' situation.

In spite of their value, these wetlands have been subject to considerable anthropogenic degradation, which has reduced their capacity to deliver ecosystem services. Some of this is through direct destructive behaviour for short term gain from agriculture, and some degradation is due to the spread of invasive trees. The draining and ploughing of wetlands for agriculture is illegal and needs to be curbed if investments in wetland rehabilitation are to be successful in the longer term. Indeed, based on the costs found in this study, the prevention of further degradation is likely to be less costly than the 'cure'. The spread of invasive trees is an accident of historical ignorance and in spite of legislation mandating the clearing of listed invasive species, the authors contend that the onus is on government to clear existing infestations, especially where this requires financial resources that are well beyond those of the local communities.

In analysing the cost-effectiveness of EbA options relative to 'conventional alternatives', it is important to frame the cost-effectiveness analysis in terms of a particular end-objective. In this case, the objective was to sustain livestock stocking rates through the dry summer months of the year under projected future climate conditions. For local applicability, this objective should address the vulnerabilities of local communities to the projected effects of climate change and the need to rehabilitate critical ecosystems on which these communities rely - in essence, the definition of EbA. Researchers need to take cognisance of the fact that, in reality, alternatives to achieving the same end-objective may not need to be implemented within the same time period. Thus the choice of discount rate in the analysis has obvious importance. While the costs associated with EbA options would usually need to be incurred in the present or near future, those associated with 'conventional alternatives' are more likely to be incurred at a much later stage, in reaction to climate changes.

\section{Conclusion}

This study presents and demonstrates through the analysis of wetland restoration in the Kamiesberg uplands, South Africa, a method for the cost-effectiveness analysis of EbA to climate change from a landowner perspective. The analysis was framed by the objective of sustaining livestock stocking rates into the future, given the predicted pressures of climate change. The implementation of 'conventional alternatives' (installation of boreholes and supply of dry feed) was found to be more cost-effective than EbA as a means of sustaining livestock stocking rates, where EbA is likely to be twice as costly. 
It is generally assumed that EbA is likely to be more cost-effective than conventional options, by capitalising on the services provided by ecosystems that help to ameliorate the impacts of climate change. However, in this study, from the perspective of landowners in a poverty-stricken arid region facing the prospect of further heat and droughts, EbA proved to be a more costly intervention than conventional measures. But if the implementation of EbA measures is done by an organisation that simultaneously addresses poverty on a broader scale, then the costs of EbA measures can effectively be discounted. The model provided by Working for Water and its related programmes in South Africa may therefore prove to be a critical strategy in implementing EbA under conditions of information scarcity and uncertainty in areas where EbA would not otherwise be implemented.

\section{References}

AGRICULTURAL RESEARCH COUNCIL - ANIMAL PRODUCTION INSTITUTE, 2012. An assessment of the condition and governance of three rehabilitated ephemeral wetlands in the Kamiesberg Uplands. AINLEY, D, PÉREZ, Á., ANDRIANARISATA, M., BARNES, J., BECK, M., BROUWER, J., GATTI, R., CHANDRA, A., CHIRAMBA, T., DALTON, J., DAVE, R., DE GROOT, D., FERDAÑA, Z., GILMER, B., HACHILEKA, E., HAJOST, S., HAMERLYNCK, O., FERNÁNDEZ, B., HOWARD, M., LAMIZANA, B., MACKINNON, J., MUÑOZ, M., NEWKIRK, S., RANDRIANARISOA, J., RASOLOHERY, A., SELOMANE, O., PÁEZ, K., TAYLOR, E., TIN, T., TRIANA, J., VAN DEN BROECK, D., VAN ECK, B., VASSEUR, L., WELCHEL, A. \& ZYLSTRA, M., 2010. Building resilience to climate change: Ecosystembased adaptation and lessons from the field. International Union for Conservation of Nature (IUCN).

BATKER, D., DE LA TORRE, I., COSTANZA, R., SWEDEEN, P, DAY, J., BOUMANS, R. \& BAGSTAD, K. 2010. Gaining ground: Wetlands, hurricanes and the economy; The value of restoring the Mississippi River Delta. Earth Economics Project Report.

BENJAMINSEN, T.A., ROHDE, R., SJAASTAD, E., WISBORG, P. \& LEBERT, T., 2006. Land reform, range ecology, and carrying capacities in Namaqualand, South Africa. Annals of the Association of American Geographers, 96(3):524-540.

BIRCH, J.C., NEWTON, A., AQUINO, C., CANTARELLO, E., ECHEVERRÍA, C., KITZBERGER, T., SCHIAPPACASSE, I. \& GARAVITO, N.T., 2010. Cost-effectiveness of dryland forest restoration evaluated by spatial analysis of ecosystem services. Proceedings of the National Academy of Sciences of the United States of America, 107(50):21925-30.

BOURNE, A., DONATTI, C., HOLNESS, S. \& MIDGLEY, G. 2012. Climate change vulnerability assessment for the Namakwa district municipality. Conservation South Africa (CSA).

CAMPBELL, A., KAPOS, V., SCHARLEMANN, J., BUBB, P., CHENERY, A., COAD, L., DICKSON, B., DOSWALD, N., KAHN, M.S.I., KERSHAW, F. \& RASHID M. 2009. Review of the literature on the links between biodiversity and climate change: Impacts, adaptation and mitigation. Secreteriat of the Convention on Biological Diversity, Montreal. Technical Series No. 42:124.

CLIMATE INFORMATION PLAFORM (CIP). 2014. http://cip.csag.uct.ac.za/. Climate Systems Analysis Group, University of Cape Town.

DEPARTMENT OF ENVIRONMENTAL AFFAIRS (DEA). 2013a. Long-term adaptation scenarios flagship research programme (LTAS) for South Africa: Climate change implications for the water sector in South Africa. Pretoria, South Africa.

DEA, 2013b. Long-term adaptation scenarios flagship research programme (LTAS) for South Africa: Climate trends and scenarios for South Africa. Pretoria, South Africa.

DOSWALD, N. \& OSTI, M. 2011. Ecosystem-based approaches to adaptation and mitigation - good practice examples and lessons learned in Europe, Bonn, Germany.

HELME, N. \& DESMET, P. 2006. A description of the endemic flora and vegetation of the Kamiesberg Uplands, Namaqualand, South Africa. Report for Critical Ecosystem Partnership Fund (CEPF) and Succulent Karoo Ecosystem Programme (SKEP).

HILL, R.C., ARCHER, F.M. \& WEBLEY, L. 1990. Conflict over change in land tenure in the reserves of Namaqualand, South Africa: A role for integrated environmental management. Impact Assessment, 8(1-2): 197-215. 
HOANG TRI, N., ADGER, W. \& KELLY, P. 1998. Natural resource management in mitigating climate impacts: the example of mangrove restoration in Vietnam. Global Environmental Change, 8(1):49-61. HUQ, N., RENAUD, F. \& SEBESVARI, Z. n.d. Ecosystem based adaptation (EbA) to climate change integrating actions to sustainable adaptation. United Nations University, Institute for Environment and Human Security (UNU-EHS).

JOB, N. 2008. Wetlands of Kamiesberg municipality. Prepared for the Critical Ecosystems Partnership Fund and Conservation International.

JONES, H.P., HOLE, D.G. \& ZAVALETA, E.S. 2012. Harnessing nature to help people adapt to climate change. Nature Climate Change, 2(7):504-509.

KOTZE, D., MALAN, H., ELLERY, W., SAMUALS, I. \& SAUL, L. 2010. Assessment of the environmental condition, Ecosystem service provision and sustainability of use of two wetlands in the Kamiesberg uplands. Report to the Water Research Commission (WRC).

KOTZE, D. \& ELLERY, W. 2008. WET-OutcomeEvaluate: An evaluation of the rehabilitation outcomes of six wetland sites in South Africa. Wetland Management Series, Water Research Commission (WRC).

LE MAITRE, D., O'FARRELL, P., MILTON, S., ATKINSON, D., DE LANGE, W., EGOH, B., REYERS, B., COLVIN, C., MAHERRY, A. \& BLIGNAUT, J. 2009. Assessment and evaluation of ecosystem services in the Succulent Karoo Biome. Report prepared for the Succulent Karoo Ecosystem Programme (SKEP) Coordination Unit.

MIDGLEY, G., MARAIS, S., BARNETT, M. \& WÅGSÆTHER, K. 2012. Biodiversity, climate change and sustainable development - Harnessing Synergies and celebrating successes. South African National Biodiversity Institute (SANBI), Conservation South Africa (CSA), and Indigo Development and Change. MUCINA, L. \& RUTHERFORD, M. 2006. Vegetation map for South Africa, Lesotho and Swaziland. South African National Biodiversity Institute (SANBI). http://bgisviewer.sanbi.org [accessed September 2013]. MUNANG, R., THIAW, I., ALVERSON, K., MUMBA, M., LIU, J. \& RIVINGTON, M. 2013. Climate change and Ecosystem-based adaptation: A new pragmatic approach to buffering climate change impacts. Current Opinion in Environmental Sustainability, 5(1):67-71.

MUNROE, R., DOSWALD, N., ROE, D., REID, H., GIULIANI, A., CASTELLIE, I. \& MÖLLER, I. 2011. Does EbA work? A review of the evidence on the effectiveness of ecosystem-based approaches to adaptation. http://www.unep-wcmc.org [accessed February 2014].

MUNROE, R., ROE, D., DOSWALD, N., SPENCER, T., MÖLLER, I., VIRA, B., REID, H., KONTOLOEN, A., GIULIANI, A., CASTELLI, I. \& STEPHENS, J. 2012. Review of the evidence base for ecosystem-based approaches for adaptation to climate change. Environmental Evidence, 1(1):13. ttp://www.environmentalevidencejournal.org/content/1/1/13.

NAUMANN, S., ANZALDUA, G., GERDES, H., FRELIH-LARSEN, A., DAVIS, M., BERRY, P., BURCH, S. \& SANDERS, M. 2011. Assessment of the potential of ecosystem-based approaches to climate change adaptation and mitigation in Europe. Final report to the European Commission, DG Environment, Contract no. 070307/2010/580412/SER/B2.

RAO, N., CARRUTHERS, T., ANDERSON, P., SIVO, L., SAXBY, T., DURBIN, T., JUNGBLUT, V., HILLS, T. \& CHAPE, S. 2012. An economic analysis of ecosystem-based adaptation and engineering options for climate change adaptation in Lami Town, Republic of the Fiji Islands. A technical report by the Secretariat of the Pacific Regional Environmental Programme.

RUSSI, D., TEN BRINK, P., FARMER, A., BADURA, T., COATES, D., FÖRSTER, J., KUMAR, R. \& DAVIDSON N.2013. The economics of ecosystems and biodiversity for water and wetlands. IEEP, London and Brussels; Ramsar Secretariat, Gland.

SAMUELS, M.I., 2013. Pastoral mobility in a variable and spatially constrained South African environment. University of Cape Town.

SCHULZE, R.E. 2011. A 2011 Perspective on climate change and the South African water sector. Water Research Commission, Pretoria, RSA, WRC Report 1843/2/11.

SECRETARIAT OF THE CONVENTION ON BIODIVERSITY. 2009. Connecting biodiversity and climate change mitigation and adaptation: Report of the Second Ad Hoc Technical Expert Group on Biodiversity and Climate Change. Montreal, Technical Series No. 41, 126 pages. 
TEEB. 2010. The economics of ecosystems and biodiversity: Mainstreaming the econmics of nature: $A$ synthesis of the approach, conclusions and recommendations of TEEB. The Economics of Ecosystems and Biodiversity (TEEB).

TINCH, R. \& LEDOUX, L. 2006. Economics of managed realignment in the UK. Final report to the coastal futures project. Environmental Futures Limited report to the Royal Society for the Protection of Birds (RSPB).

UNFCC, Database on ecosytem-based approaches to adaptation. https://unfccc.int/adaptation/nairobi_work_ programme/knowledge_resources_and_publications/items/6227.php [accessed February 2014].

VIGNOLA, R., LOCATELLI, B., MARTINEZ, C. \& IMBACH, P. 2009. Ecosystem-based adaptation to climate change: what role for policy-makers, society and scientists? Mitigation and Adaptation Strategies for Global Change, 14(8):691-696. http://link.springer.com/10.1007/s11027-009-9193-6 [accessed January 2014].

WORKING FOR WETLANDS. 2013. Kamiesberg wetland rehabilitation data. Department of Environmental Affairs (DEA), Department of Water and Sanitation (DWS), and Department of Agriculture, Forestry and Fisheries (DAFF).

ZIERVOGEL, G., NEW, M., VAN GARDEREN, E.A., MIDGLEY, G., TAYLOR, A., HAMANN, R., STUART-HILL, S., MYERS, J. \& WARBURTON, M. 2014. Climate change impacts and adaptation in South Africa. Wiley Interdisciplinary Reviews: Climate Change, 5(5):605-620.

http://doi.wiley.com/10.1002/wcc.295 [accessed November 2014]. 